\title{
IMPLIKASI ETIKA SOLIDARITAS KNUD EJLER LOGSTRUP TERHADAP KORBAN VIRUS COVID-19 DI INDONESIA
}

\section{Kosmas Sobon}

Universitas Katolik De La Salle Manado

Email: ksobon@unikadelasalle.ac.id

\section{Timoteus Ata Leu Ehaq}

Sekolah Tinggi Filsafat Seminari Pineleng

\section{Abstrak}

Tujuan utama artikel ini adalah memahami dan menganalisis secara kritis etika solidaritas Knud Ejler Løgstrup dan implikasinya terhadap korban Covid-19 di Indonesia. Metode penelitian adalah penelitian pustaka dengan menggunakan metode hermeneutika. Hasil penelitian menunjukkan bahwa pemikiran solidaritas Løgstrup menjadi dasar untuk solider terhadap terhadap korban Covid-19, solidaritas atas korban Covid-19 bukan sekedar perasaan, tidak bersifat normatif, selalu bersifat asimetris, sebuah fenomena moral dan ciri khas dari cinta.

Kata kunci: Etika, Solidaritas, Knud Ejler Løgstrup, Virus Covid-19.

Abstract

The purpose of this article is to understand and analyze critically and sharply about the solidarity's ethics of Knud Ejler Løgstrup and its implications for the victims of Covid-19 in Indonesia. The research method is library research using the hermeneutic method. The results of research showed Løgstrup's thought of solidarity became the basis for solidarity on victims of desease Covid-19, solidarity on victims of Covid-19 was not just a feeling, it was not normative, always asymmetrical, a moral phenomenon and the hallmark of love.

Keywords: Ethics, Solidarity, Knud Ejler Løgstrup, Virus Covid-19. 


\section{PENDAHULUAN}

Virus Corona atau Covid-19 yang sedang melanda masyarakat dunia saat ini menjadi pandemi global yang diakui oleh World Health Organization (WHO) dengan tingkat penyebarannya yang begitu cepat. Berdasarkan data dari detik.com per 20 Februari 2021 pukul 16.15 WIB ditemukan bahwa virus Corona secara nasional menunjukkan 1.263.299 orang terinfeksi positif, 34.152 orang meninggal dunia dan 1.069 .005 dinyatakan sembuh. Tentunya angka-angka ini terus mengalami perkembangan setiap hari. Berbagai upaya dan kebijakan yang sudah dibuat dan diterapkan oleh pemerintah baik pemerintah pusat, daerah, hingga di pelosok tanah air untuk meminimalisir, mencegah dan memutus rantai penyebaran virus Covid-19 ini. Semua usaha dan kebijakan tersebut juga belum mendapatkan hasil yang signifikan.

Untuk menghadapi realitas para korban virus Covid-19 ini, maka sangat diperlukan sebuah kesadaran individu dan sebuah tindakan etis manusia terhadap yang lain. Kesadaran moral secara personal ini bisa mencegah penyebaran virus Covid-19 sekaligus penghargaan bagi para korban Covid-19 sebagai manusia yang hidup. Kesadaran etis yang dimaksud adalah kesadaran manusia secara individual. Untuk menjelaskan gagasan ini, penulis bertitik tolak pada gagasan etika solidaritas Knud Ejler Løgstrup. Hasil pemikiran Løgstrup dapat menjadi dasar bagi seorang individu untuk beretika dengan menggunakan prinsip solidaritas di tengah wabah virus Corona yang melanda tanah air saat ini. Tindakan solidaritas atas orang lain dapat dijadikan titik awal bagi tindakan etis bagi para korban virus Covid-19.

Etika solidaritas Løgstrup ini merupakan inspirasi yang paling kuat terasa dari etika komunikatif yang dikemukakannya, di mana ia sangat menekankan rasa tanggung jawab terhadap nasib sesama manusia. Tanggung jawab itu bercorak universal, karena merupakan tuntutan etis bagi setiap orang. Hal ini berbeda dengan teori-teori etika lain yang mengajarkan bahwa tanggung jawab itu berdasarkan rasionalitas. Pemikirannya ini dilatarbelakangi oleh identitasnya sebagai seorang teolog, di mana hidup benar-benar 
dipahami sebagai individu yang harus mencintai, solider dan senasib demi kesejahteraan dan kebaikan sesama, tanpa memandang batasan sosial, kultural, politik maupun agama. Perhatian dan tuntutan etis terhadap nasib orang lain merupakan tuntutan eksistensial yang sudah begitu saja sebagai bagian dari kenyataan interdependensi (Bauman, 1993).

Menurut Løgstrup, status ontologis hakikat kodrat manusia berarti kodrat itu "terberi." Di hadapan manusia, kodrat itu "ada begitu saja." Muatan fundamental dari hakikat kodrat itu adalah tanggung jawab, dalam arti "hidup bagi orang lain." (Løgstrup, 1971). Penegasan ini mengandung makna bahwa secara ontologis manusia hidup bagi orang lain; kenyataan ini mendahului fakta eksistensial bahwa ia hidup dengan orang lain. Makna hakikat kehidupan sesungguhnya terletak pada "hidup bagi" dan bukan sekedar "hidup dengan" orang lain. Artinya perhatian dan tanggung jawab yang diberikan mendahului kesadaran rasional; karena ia berada pada lapisan "terberi" yang tidak selalu dapat diartikulasikan.

Hakikat ontologis kodrat manusia, dengan muatan tanggung jawab menyatakan diri melalui apa yang disebut Løgstrup "manisfestasi-manifestasi tertinggi dari kehidupan." Yang dimaksud adalah cinta, rasa prihatin, kepercayaan, keterbukaan dalam percakapan, harapan, kemarahan dalam arti yang positif. Sedangkan manifestasi-manifestasi itu mempunyai karakteristik sebagai berikut: spontan, berdaya-cipta, dan definitif. Dalam bahasa tradisional, bentuk-bentuk manifestasi yang disebut Løgstrup sebagai kebajikan. Tetapi bukan hal tersebut yang dimaksudkan oleh Løgstrup. Baginya, manifestasi-manifestasi tersebut merupakan cara berada yang bermakna dan secara potensial terkandung dalam kodrat manusia.

Selanjutnya, Løgstrup menerangkan bahwa manifestasimanifestasi itu bercorak "spontan," artinya bebas dari paksaan ataupun motif-motif yang tersembunyi. Misalnya, menolong seseorang yang berada dalam keadaan sulit dengan motif bahwa jika orang seperti itu terlampau banyak dalam suatu masyarakat 
maka stabilitas masyarakat akan terganggu. Motif seperti ini mentransformasikan keprihatinan menjadi sebaliknya: ketidakacuhan terhadap penderitaan orang lain.

Manifestasi kehidupan berdaya-cipta, artinya suatu tindakan tidak terutama merupakan reaksi, tetapi terlebih suatu keterlibatan yang mengubah situasi atas usaha si pelaku. Løgstrup menolak bahwa karakteristik ini menyatakan bahwa dengan demikian manusia sama sekali berdaulat atas dirinya. Itulah hanyalah suatu ilusi. Yang benar ialah bahwa kehidupan ini merupakan suatu anugerah (Løgstrup, 1971).

Akhirnya, Løgstrup menjelaskan bahwa manifestasimanifestasi kehidupan ini merupakan fakta deskriptif dari eksistensi manusia dan tuntutan normatif saling berpaut. Artinya, manifestasi-manifestasi itu merupakan kenyataan eksistensialobyektif, dan sekaligus juga berfungsi sebagai posibilitas yang membebaskan manusia.

Uraian singkat etika Løgstrup di atas secara tidak langsung memberikan dampak yang sangat signifikan terhadap para korban virus Covid-19. Pandemi virus Covid-19 saat ini menghantar setiap individu untuk menyadari manifestasi-manifestasi kehidupannya tertingginya untuk bersolider, mencintai, berbagi dan beretika dengan para korban virus Covid-19. Tindakan etis terhadap korban virus Covid-19 bukan hanya dalam bentuk rasa atau motivasi psikologis seperti simpati, keprihatinan, cinta atau tanggung jawab melainkan suatu sikap atau cara berada di mana totalitas personal terlibat. Artinya sikap solidaritas yang diberikan kepada korban Covid-19 menjadi konvergensi (kesatuan) dari pengertian, persepsi, perasaan dan kehendak. Sebagai suatu sikap eksistensial, solidaritas memiliki ciri khas keterbukaan yang serius terhadap persamaan fundamental (fundamental equality) dari semua manusia dan keberanian untuk menghadapi tantangan demi kebaikan dunia dan manusia.

Oleh karena itu, dalam bingkai pemikiran inilah menurut Løgstrup setiap individu wajib mengaktualisasikan manifestasimanifestasi kehidupannya yang tertinggi untuk mencintai sesama 
secara spontan, berdaya-cipta dan definitif seperti memberikan pertolongan pada korban Covid-19 tanpa pertimbangan untungrugi. Dengan demikian solidaritas bersifat etis karena menekankan tindakan yang dituntut demi kemanusiaan.

Fokus penelitian ini adalah mengkaji dan menganalisis konsep solidaritas Løgstrup serta mengimplikasikannya ke dalam masalah sosial masyarakat di Indonesia khususnya dalam bertindak solider terhadap korban virus Covid-19. Kekhasan utama penelitian ini terletak pada analisis konsep solidaritas Løgstrup yang bercorak metafisika namun memiliki relevansi yang fundamental dan bermakna bagi kehidupan nyata manusia terlebih pada aspek relasi interpersonal dengan sesama. Dengan kata lain, penelitian ini lebih terfokus pada perilaku etis setiap individu terhadap korban virus Covid-19 di Indonesia dalam perspektif solidaritas yang dikemukakan oleh Løgstrup.

\section{PEMBAHASAN}

\section{KONSEP ETIKA LØGSTRUP}

\section{Riwayat Hidup Logstrup}

Knud Ejler Løgstrup adalah seorang teolog yang profesional, tapi kenyataannya dia juga adalah seorang filsuf etika yang hebat dari Denmark (Bauman, 1993). Ia lahir pada tanggal 2 September 1905 di Copenhagen. Ia studi teologi di sana sejak tahun 1923 dan lulus pada tahun 1930. Selama studinya, dia mengikuti ceramah Frithiof Brandt tentang Kant's Critique of Pure Reason selama 2 tahun. Setelah lulus ia mendapat beasiswa ke Eropa dan belajar dengan beberapa pemikir terkemuka seperti Martin Heidegger di Freiburg, Hans Lipps dan Friedrich Gogarten di Gottingen dan Jean Hering di Strasbourg. Di samping itu, ia juga menghadiri ceramah dari Henri Bergson di Paris dan Moritz Schlick di Wina. Dari beberapa pemikir tersebut, Heidegger, Lipps dan Gogarten memiliki pengaruh yang paling besar bagi pemikirannya dan membawanya lebih jauh ke dalam pemikirannya tentang tradisi Fenomenologi pasca-Husserlian. Karya pertama Løgstrup tahun 1932 dengan judul "Max Scheler's Formalism in Ethics and Non-Formal Ethics of 
Value." Ia menyelesaikan program doktor pada tahun 1933 dengan judul disertasi "The Epistemological Conflict Between Transcedental Idealism and Theology." Kemudian pada tahun 1943 mendapat gelar profesor bidang Etika dan Filsafat Agama di Fakultas Teologi Universitas Aarhus hingga pensiun pada tahun 1975 (Stern, 2019)

Dia sendiri berpikir seperti seorang fenomenolog dan merasa berhutang budi pada Husserl serta Heidegger dan juga kepada Hans Lipps. Di samping itu, pemikirannya juga sangat dipengaruhi oleh dua tradisi besar dari budaya Denmark, yakni tulisan-tulisan asli Kierkegaard dan karya-karya dari N. F. S. Grundtvig (17831872). Ia tidak terkenal layaknya Levinas, tetapi keduanya dapat diperbandingkan hasil pemikiran mereka karena kedua filsuf ini memiliki pemikiran yang sama dan serupa mengenai makna terdalam dari relasi antar manusia.

Karya tulis Løgstrup berfokus pada dua hal penting yakni etika dan metafisika. Bukunya yang berbicara tentang etika adalah The Ethical Demand (1956) dan Norm and Spontaneity (1972) (Thomassen, 1992). Selanjutnya, buku metafisikanya yang berjudul Metaphysics terdiri dari empat volume, yakni: Linguistic Philosophy (vol. I), Esthetics (vol. II), Philosophy of Nature and History (vol. III) dan Philosophy of Religion (vol. IV); Solidarity and Love (1987). Titik tolak etikanya secara penuh berbicara tentang manusia. Menurutnya, etika itu telah bertumbuh sebelum adanya perintah agama, perintah pemerintah, ataupun perintah lain. Etika mendahului pesan-pesan agama. Dalam pengertian ini, etika harus dipahami sebagai: "iman tanpa pengertian adalah bukan iman melainkan paksaan" (Løgstrup, 1971). Løgstrup juga terkenal dengan etika permintaan (the ethical demand) yang baginya menjadi kekuatan dalam suatu relasi interpersonal. Ia meninggal dunia pada tanggal 20 November 1981.

\section{Etika Solidaritas}

Kata Solidaritas pertama-tama muncul di Perancis dalam suatu periode persis sebelum revolusi 1789, dan kemudian 
diadaptasikan oleh bahasa-bahasa Eropa dengan arti yang umumnya sama saja. Solidaritas berarti memiliki rasa setia-kawan dengan orang lain (a sense of togetherness with others), memiliki rasa kesatuan perhatian dan kepentingan; atau berdiri bersama dan bergumul bersama dengan orang lain demi suatu ide, kepentingan ataupun untuk saling membantu. Menurut Oxford English Dictionary, "solidaritas" berarti suatu perasaan kebersamaan dengan orang lain, suatu kesatuan kepentingan; sedang berdiri bersama-sama, sedang tetap bersatu, sedang berunding bersamasama untuk suatu gagasan, suatu kepentingan, untuk saling menolong satu sama lain (Thomassen, 1992). Sedangkan Ensiklopedi Nasional Indonesia, solidaritas berarti rasa senasib sepenanggungan, kesetiakawanan dan kebersamaan. Dalam solidaritas ada semangat kepedulian seseorang, suatu kelompok atau masyarakat atas nasib orang lain. Sikap itu muncul dari sifat manusia sebagai makhluk individu sekaligus makhluk sosial (Sudibjo, 2004). Dari uraian singkat di atas dapat disimpulkan bahwa solidaritas dapat diartikan sebagai suatu sikap dan tindakan kesetiakawanan dengan orang lain karena punya satu tujuan, yakni menolong dan memelihara kehidupan sesama. Jadi, tindakan solidaritas itu ditujukan kepada pribadi yang lain

Konsep solidaritas yang dijelaskan di atas memiliki arti dan makna yang berbeda dengan pemahaman etika solidaritas Løgstrup. Titik tolak etika Løgstrup secara penuh berbicara tentang manusia. Etika seharusnya mempertunjukkan karakteristik eksistensi manusia, dan etika itu telah bertumbuh sebelum adanya perintah agama bahkan mendahului pesan-pesan agama. Menurut Løgstrup ada sejumlah kemungkinan-kemungkinan yang baik dalam diri manusia, yang dia sebut sebagai manifestasi-manifestasi yang berkuasa dari kehidupan. Dalam diri manusia terkandung kekuatan-kekuatan kebaikan demi membantu orang lain. Kekuatan itu perlu dibagikan dalam relasi interpersonal dengan orang lain, sebelum orang lain menuntut suatu kebaikan. Artinya, kebaikan dalam diri manusia mendahului segala peraturan baik peraturan dari agama, peraturan pemerintah, maupun peraturan yang ada 
dalam hidup masyarakat. Løgstrup terkenal dengan tuntutan etis (the ethical demand) yang baginya menjadi kekuatan dalam suatu relasi interpesonal.

Permintaan etis itu tidak disuarakan atau disampaikan. Orang lain bukanlah suatu kekuatan melainkan sebuah Wajah. Orang lain itu hanya kekuasaan, dan kekuasaan itu tidak butuh kekuatan. Jadi perintah untuk memelihara, atau "ada untuk", telah ada sebelum tuntutan disampaikan. Jadi, sebelum orang lain meminta, saya sudah memelihara kehidupannya; saya telah lebih dahulu bersikap moral terhadapnya, karena tuntutan itu tak terkatakan. Oleh karena itu, Løgstrup menjelaskan,

Tuntutan itu bersifat radikal, karena tepat hal itu tidak disuarakan...bagaimana pun juga penting atau tidak penting dilaksanakan supaya tampak di luar, tuntutan itu radikal karena dalam setiap sifat dasar tidak ada orang tapi dia sendirian, lewat sifatnya sendiri yang tidak mementingkan diri, seharusnya menemukan apa akan terbaik melayani pribadi yang lain...Permintaan itu punya pengaruh dalam pembentukan pribadi yang kepadanya permintaan diarahkan dalam pengertian kata yang tepat...radikalitas itu mewujudkan dirinya sendiri juga dalam kenyataan pribadi yang lain tidak punya hak sendiri untuk membuat permintaan (Bauman, 1993).

Løgstrup ingin menunjukkan bahwa seseorang menjadi bermoral karena ada dorongan untuk melakukan, bukan pengetahuan tentang apa yang dibuat; tugas yang tidak ditepati; atau kewajiban yang telah dilaksanakan dengan benar. Løgstrup mengatakan, "pada kenyataannya bahwa seorang pribadi tidak pernah dapat yakin sepenuhnya bahwa dia telah bertindak dengan cara yang benar," (Bauman, 1993). Selama hidup di dunia, orang perlu merasa bahwa dia belum berbuat baik kepada orang lain, oleh karena itu ia selalu didorong untuk berbuat baik terus menerus. Hal ini sejalan dengan apa yang dikemukakan oleh Norlyk dkk (2011) 
yakni tulisan Løgstrup berkonsentrasi terutama pada analisis fenomena kehidupan nyata seperti kepercayaan, keberanian hidup, kekuatan dan harapan. Akibatnya, filsafat Løgstrup sering disebut sebagai "filsafat hidup" karena fokusnya pada fenomena eksistensial yang berkaitan dengan pemenuhan hidup (Delmar, 2006; Pahuus, 1993). Pemenuhan hidup memerlukan perasaan hidup, keberanian hidup, rasa koherensi, kegembiraan hidup itu sendiri.

\section{Landasan Etika Løgstrup}

Etika Løgstrup berfokus secara radikal pada aspek hubungan relasi antar subyektif yang memiliki signifikansi bagi pemikiran dan teori etika. Sejak awal fokus filsafatnya adalah pada antropo-fenomenologi dan yang kemudian bergerak ke arah kosmo-fenomenologi (Jensen, 2007). Ia memosisikan etikanya sebagai sebuah solusi alternatif dari dua tradisi etis yang dominan dalam filsafat Barat yakni teleologi dan deontologi. Løgstrup berpendapat bahwa meskipun secara benar kita terlibat dengan orang lain, namun kita tidak membutuhkan aturan-aturan moral untuk memandu tindakan kita, melainkan kita kehilangan keterlibatan tersebut, saat aturan itu diperlukan. Oleh karena itu, kita membutuhkan aturan untuk melindungi kekurangan dan egosentrisitas kita (Randi et al., 2020).

Dasar etika Løgstrup tidak bisa dipisahkan dengan konsepnya tentang fenomenologi. Konsep fenomenologi yang terdapat dalam etika situasi ontologi Løgstrup memiliki empat nilai inti yang sangat penting yakni: (1) sensasi dan klaim etis; (2) gagasan apa yang Løgstrup sebut sebagai ucapan kehidupan tertinggi; (3) bentuk eksistensial dari ekspresi kesan; dan (4) pemahaman kehidupan puitis dan etis (Pahuus, 2005).

\section{Pengaturan sensasi dan klaim etis}

Pemahaman fenomenologi Løgstrup berbeda dengan konsep fenomenologi yang dimengerti pada abad ke-19 seperti Husserl dan Heidegger. Edmund Husserl misalnya mengedepankan gagasan 
bahwa kesadaran selalu merupakan kesadaran akan sesuatu (disengaja), dan Heidegger lebih menekankan bahwa orang dilemparkan ke dunia; selalu berada di dunia. Sementara itu, Løgstrup menentang kemungkinan posisi netral dan karakteristik terpisah dari modernisme, positivisme dan nilai-nilai pencerahan yang mendasari sains. Ia menyatakan bahwa kita tidak dapat memahami kehidupan manusia terpisah dari waktu dan tempat di mana kita berada. Manusia seharusnya tidak berusaha menjadikan dunia sebagai objek kendalinya. Løgstrup menegaskan bahwa kehidupan manusia terjalin di dunia melalui apa yang disebutnya 'sensasi'.

Menurut Løgstrup, 'kita diatur dalam sensasi' oleh kesankesan, yang terus-menerus membentuk dan menyempurnakan ekspresi kita. Sensasi itu diatur saat kita menghadapi situasi baru. Dalam arti itulah, kita dihantar untuk lebih dekat ke diri kita sendiri. Kondisi baru tersebut menantang kita untuk bersikap dan memahami diri lebih baik. Løgstrup berpendapat bahwa dengan bersikap terbuka pada diri kita sendiri dan hubungan kita dengan dunia, maka kita dapat melakukannya 'datang ke diri kita' dalam sensasi dan dalam emosi kita (Løgstrup, 1987).

Sensasi itulah yang membawa kita untuk dapat tergerak oleh apa yang dipertaruhkan untuk orang lain dalam situasi tertentu. Oleh karena itu, klaim etis dapat digambarkan sebagai kesan yang disesuaikan tentang bagaimana seseorang yang membutuhkan bantuan. Kesan yang diatur seperti itu menggerakkan kita untuk bertindak. Kita ditantang untuk menemukan cara bagaimana untuk bertindak.

\section{Saling ketergantungan manusia dan ucapan kehidupan tertinggi}

Ciri kedua dari etika Løgstup berkaitan dengan fenomena kehidupan seperti kepercayaan, harapan, kasih sayang, belas kasihan, dan ucapan terbuka, yang disebutnya sebagai ucapan kehidupan berdaulat. Fenomena tersebut bukan pencapaian pribadi, atau kualitas yang dimiliki individu, tetapi lebih diberikan oleh kehidupan itu sendiri. Kualitas sikap itu muncul secara 
spontan, secara anonim terbentang di antara sesama yang mengarahkan seseorang secara natural berelasi satu sama lain. Misalnya, kepercayaan dikondisikan pada koeksistensi timbal balik. Hal ini muncul saat yang lain menerima kita. Hadirnya relasi satu sama lain ada dalam saling ketergantungan manusia, dan saat itulah sikap kepercayaan muncul. Hal itu bukan berasal dari suatu kemauan, tapi hadir dalam setiap hubungan dengan yang lain. Dalam istilah Løgstrup (1997), ucapan kehidupan berdaulat bertindak di belakang kita. Ia menegaskan bahwa kita menjadi diri kita sendiri ketika didukung oleh ucapan kehidupan berdaulat.

Berbicara secara terbuka merupakan salah satu fenomena yang digambarkan Løgstrup sebagai ungkapan kehidupan berdaulat. Berbicara secara spontan saat seseorang tergerak oleh kesan. Seseorang harus secara aktif menahan diri agar tidak mengungkapkan atau mengatakan yang sebenarnya. Titik berangkat Løgstrup adalah bahwa setiap orang memiliki semacam zona pribadi yang tidak boleh diganggu atau diketahui siapa pun. Dalam proses interaksi sosial, kita selalu berada dalam dua situasi yakni berbicara secara terbuka dan menahan diri. Untuk mencegah berbicara secara terbuka dan spontan berubah menjadi ungkapan yang tidak berkualitas, gosip yang tidak dipikirkan, rasa malu atau bahkan ofensif, maka di situlah ucapan kehidupan berdaulat terbuka.

\section{Membentuk ekspresi kesan-norma moral dan praktek etis}

Menurut Løgstrup seseorang tidak akan pernah bisa terlibat dengan orang lain tanpa memegang sesuatu dari kehidupan orang lain (Løgstrup, 1997). Løgstrup berpendapat bahwa mungkin tidak mudah untuk menafsirkan situasi ini; untuk memahami apa yang dikorbankan bagi orang lain selain diri kita sendiri. Klaim etis jarang eksplisit, dan bagaimana menanggapinya biasanya tidak pasti. Tanggapan khusus tidak diminta. Kita dipanggil untuk memutuskan bagaimana kita memilih untuk bertindak. Kita bebas bertanya apa yang kita rasakan? Apa sebenarnya arti klaim ini? Apa yang dibutuhkan orang lain? Apa yang sebenarnya saya berikan 
kepada orang lain? Apa peran, tanggung jawab, dan kemungkinan kita dalam situasi ini? Ketika digerakkan oleh klaim etis, Løgstrup berpendapat, kasih sayang adalah kekuatan pendorong. Løgstrup tidak menawarkan panduan atau pedoman tentang bagaimana kita bertindak, melainkan mengakui bahwa, dalam situasi sulit, kita membutuhkan dukungan norma, aturan, dan regulasi yang berbentuk budaya. Tanggung jawab bersifat universal bagi manusia. Kita bebas memutuskan seberapa banyak kehidupan orang lain yang siap kita perjuangkan. Kadang-kadang, tanggung jawab yang kita pegang terasa ringan dan mudah, di lain pihak bisa sangat membebani.

Yang penting Løgstrup berpendapat bahwa klaim etis yang muncul dari situasi orang lain, bukan menuntut suatu permintaan. Ini bukan permintaan untuk bersikap pasif atau ekspresi kesediaan seseorang untuk menyerahkan tanggung jawab kepada orang lain. Sebaliknya, klaim etis membuka ruang untuk keterlibatan yang tidak pasti dan dinegosiasikan. Dalam situasi seperti itu, aturan, regulasi, prosedur, dan norma sosial budaya dapat mendukung, tetapi mereka akan selalu tidak cukup untuk tugas yang ada. Løgstrup tidak menjelaskan apa yang benar atau salah secara moral. Sebaliknya, perhatiannya adalah bagaimana kita menggunakan norma dalam interaksi. Ia mengingatkan kita bahwa norma bukan milik siapa pun secara khusus, tetapi norma muncul dalam ruang sosial budaya antar manusia.

\section{Pemahaman puitis sensual yang diselaraskan tentang kehidupan dan praktik etika}

Løgstrup berpendapat bahwa kita digerakkan oleh bahasa sehari-hari baik dalam bentuk ekspresif dan semantik. Misalnya bahasa puitis ini memiliki kapasitas untuk membawa isu-isu etis dan mendasar seperti kerentanan, kasih sayang, dan saling ketergantungan (Løgstrup, 1997).

Dia berpendapat bahwa dimensi terbuka atas pemahaman puitis tentang kehidupan memiliki dasar yang sama dan sangat diperlukan untuk memahami masalah etika. Baik pemahaman etis 
maupun puitis muncul dari pengalaman hidup di mana orangorang saling berhubungan satu sama lain; terlaksana dan terjalin dalam sensasi terbuka. Pemahaman puitis dapat mengungkap makna eksistensial. Dalam penulisan puisi, ada hubungannya dengan nada dan gerak tubuh yang terkandung dalam ritme dan resonansi, gambar dan metafora mereka, dan dengan demikian tetap halus dan sulit dipahami, membutuhkan kehadiran dan keterbukaan yang konstan terhadap yang lain (Løgstrup, 1997).

Saat dihadapkan pada klaim etis, seseorang ditantang oleh kebutuhan untuk memahami kerentanan orang lain. Jadi, bagaimana seorang siap untuk bertindak, dan diwujudkan dalam bentuk tindakan, mencerminkan dan membentuk kepribadiannya. Apa yang dipilih seseorang untuk dilakukan, menunjukkan siapa dia. Mungkin ada konflik antara klaim etis yang berasal dari pihak lain, dan keinginan pribadi dan eksistensial kita untuk bertindak. Løgstrup mengakui bahwa jarak yang diberikan oleh pemikiran yang masuk akal dapat membantu kita untuk menjelaskan arti dari kekuatan, sedangkan puisi dapat membangkitkan pengalaman langsung dari mereka (Løgstrup, 2000). Løgstrup berpendapat bahwa pemahaman puitis menerangi dan membawa kita lebih dekat ke konflik etis yang ada dalam setiap relasi yang terjadi, sedangkan pendekatan yang didukung oleh objektivitas dan pelepasan menarik untuk dijauhi.

Wladyslaw Bartoszewski menambahkan "hanya orang-orang yang telah mati dan telah banyak membawa pertolongan dapat mengatakan bahwa mereka telah berbuat cukup" (Bauman, 1993). Bauman melukiskan konsep etika Løgstrup mengenai tindakan moral demi orang lain seperti sikap penyerahan diri dari orangorang kudus. Sikap penyerahan diri selalu diarahkan kepada siapa saja, baik kepada orang lain yang sudah dikenal maupun orang asing" " (Bauman, 1993). Santo menjadi santo karena mereka tidak bersembunyi di belakang tanggungan hukum. Mereka tahu, mereka merasa atau bertindak untuk merasakan penderitaan orang lain. Mereka tidak segan-segan menyerahkan tenaga dan hidup mereka untuk kewajiban moral dan bahkan menemukan akibat demi "ada 
untuk" (being for) sampai akhir hidup mereka, pilihan paling terakhir, yakni hidup atau mati. Bertindak moral harus siap dan rela menjadi korban demi kehidupan orang lain. Etika Løgstrup ini sejajar dengan etika tanggung jawab Levinas, seseorang hidup untuk menebus orang lain. Tujuan hidup manusia adalah menghidupi dan menyelamatkan sesama.

Løgstrup mengklaim bahwa untuk jangka waktu yang lama, dan terutama berkat pengaruh Kant, satu-satunya fokus etika adalah penghormatan terhadap kemerdekaan orang lain (1956). Dalam konteks ini, setiap orang dipandang sebagai dunia bagi dirinya sendiri. Menurut Løgstrup, ini adalah pandangan yang tidak memadai tentang kondisi manusia. Ketergantungan saya pada orang lain tidak bisa dihindari; hidup seorang individu saling terkait satu sama lain, dan etika tidak hanya terdiri dari "hidup dan biarkan hidup." Dengan tindakan tersebut, seseorang berkontribusi pada kualitas hidup orang lain. Inilah yang Løgstrup maksudkan dengan memiliki sebagian hidup orang lain di tangan saya. Apa kehidupannya di tangan saya dapat berkisar dari pengaruh fana ke seluruh nasibnya.

\section{IMPLIKASI SOLIDARITAS LØGSTRUP BAGI KORBAN VIRUS COVID-19}

Berdasarkan beberapa uraian tentang etika solidaritas Løgstrup tersebut maka dapat disintesiskan bahwa hasil pemikiran khususnya dalam bidang etika sangat fundamental khususnya dalam relasi dengan orang lain. Menurutnya tanggung jawab atas orang lain menjadi nyata saat seseorang bersikap solider dengan sesama. Berikut ini dijelaskan beberapa gagasan Løgstrup dan implikasinya bagi tindakan moral terhadap korban virus Covid-19 di Indonesia. Pemikiran Løgstrup memberikan arah untuk beretika dengan prinsip solidaritas pada masa pandemi virus Corona yang melanda tanah air. Tindakan solidaritas atas orang lain dapat dijadikan titik awal pemecahan masalah virus Covid-19. 


\section{Solidaritas atas Korban Covid-19: Bukan Sekedar Perasaan}

Menurut Løgstrup sikap solidaritas bukan sekedar perasaan terhadap orang lain, melainkan ikut langsung merasakan penderitaan dan ketidakbahagiaan orang lain. Tindakan etis haruslah kongkret. Bagi Løgstrup tindakan solider terhadap pasien Covid-19 baik mereka yang berstatus positif, orang dalam pemantauan (ODP) maupun orang dalam pengawasan (PDP) muncul bukan sekedar adanya dorongan lewat perasaan saja. Solidaritas terhadap korban virus Corona adalah suatu kesatuan dari pengertian, persepsi, perasaan dan kehendak (Thomassen, 1992). Hal ini berarti bahwa solidaritas bukanlah sekedar perasaan, melainkan suatu sikap atau cara berada di mana totalitas personal terlibat.

Sikap solider melampaui segala perasaan manusia. Artinya unsur terdalam dari solidaritas adalah mengenal dan merasakan penderitaan dan ketidakbahagiaan yang dialami oleh pasien Covid19. Bukti seorang individu merasakan penderitaan korban Covid 19 dalam bingkai pemikiran Løgstrup adalah bersedia menjadi relawan dalam rangka membantu percepatan penanganan pasien yang terjangkit virus Corona maupun mereka yang kini berada dalam kategori pasien dalam pengawasan (PDP). Sebagai sikap eksistensial, solidaritas dicirikhaskan oleh keterbukaan yang serius terhadap persamaan fundamental (fundamental equality) dari semua manusia, dan keberanian untuk menghadapi tantangan demi kebaikan manusia.

Saat ini negara sangat membutuhkan ribuan relawan, medis, dokter dan siapa saja yang bersedia dan rela membantu secara nyata untuk penanganan korban virus Corona. Bahkan sampai saat ini sudah banyak dokter, tenaga perawat dan medis yang telah tertular penyakit virus Corona hingga meninggal dunia demi tindakan kemanusiaan. Mereka bukan hanya menjalankan tugas dan profesinya, melainkan telah bertindak solider secara nyata sebagai bentuk kepedulian nyata mereka terhadap korban virus Covid-19. Para relawan tersebut sangat memerlukan dukungan moral untuk membuat mereka tidak kehilangan semangat dalam bertugas, 
termasuk para korban wabah Covid-19 untuk menambah semangat hidup mereka. Realitas inilah yang menurut Løgstrup sebagai sikap solidaritas nyata di mana setiap individu merasakan langsung penderitaan, luka, kesusahan, dan ketidakbahagiaan para korban virus Covid-19. Penderitaan dan masalah yang dialami oleh pasien virus Covid-19 menjadi juga penderitaan dan masalah bersama sebagai masyarakat Indonesia yang beretika. Dengan kesadaran moral inilah, hidup seseorang sebagai manusia sungguh-sungguh bermakna bagi sesama. Permintaan Etis terhadap korban Covid-19 menjadi tanda bahwa manusia saling bergantung satu sama lain. Bahkan Løgstrup menegaskan bahwa permintaan untuk merawat orang lain adalah tidak terucapkan atau diam (Stern, 2019).

Jadi, titik tolak tindakan solidaritas adalah tindakan memperlakukan korban virus Covid-19 sebagai manusia, bukan sebaliknya membuat mereka semakin menderita (Thomassen, 1992). Mereka pantas dihargai, diterima sebagai manusia bukan sebaliknya dikucilkan, dibuang, atau disingkirkan. Penegasan solidaritas Løgstrup ini sebenarnya ingin mendobrak akan stigma negatif bagi pasien ODP, DPD, keluarga dan petugas kesehatan yang menangani pasien virus Covid-19. Perasaan takut, cemas, dan bingung terhadap situasi ini dapat dimengerti tapi bukan berarti seseorang boleh berprasangka buruk bahkan mengucilkan serta mengisolasi secara radikal terhadap penderita virus Covid-19, keluarga korban, dan perawat yang menangani pasien virus Covid19.

Sikap sederhana lain yang bisa dilakukan sebagai bukti solidaritas yang nyata bagi hidup orang lain adalah mengindahkan larangan pemerintah tentang penanggulangan virus Corona seperti social distancing, tidak berada dalam kerumunan orang, stay at home, menjaga kebersihan lingkungan, penggunaan masker setiap hari dan kebiasaan mencuci tangan. Contoh tindakan sederhana seperti ini adalah wujud solidaritas nyata terhadap seorang individu, keluarga, masyarakat dan orang lain sekaligus bukti keprihatinan terhadap korban dan kewaspadaan terhadap penyebaran wabah ini di Indonesia. 


\section{Solidaritas atas Pasien Covid-19 Tidak Bersifat Normatif}

Bagi Løgstrup, solidaritas sebagai suatu dasar prinsip etika bukanlah muncul dari suatu sikap yang lahir dari norma moral. Artinya ia menganggap tuntutan etis lebih penting daripada norma sosial atau prinsip moral. Prinsip dan norma semacam itu tidak bisa diabaikan begitu saja (Løgstrup, 1997), dan itu bisa membuat seseorang bertindak seperti yang seharusnya dilakukan seandainya disadari sebagai tuntutan etis; karena alasan itu mereka berguna secara moral. Etika, bukan konstitutif untuk melakukannya sebagaimana diasumsikan oleh filsafat moral arus utama. Permintaan etis mengandung analisis fenomena konkret seperti kepercayaan, yang Løgstrup mengerti sebagai dasar kehidupan moral. Ia melanjutkan dengan penegasan bahwa:

"Dengan sikap saya terhadap orang lain, saya membantu membentuk dunia orang itu. Saya membantu menentukan ruang lingkup dan ruang dunianya; oleh karena itu saya membuatnya besar atau kecil, cerah atau menjemukan, kaya atau kusam, mengancam atau aman. Saya membantu membentuk dunianya bukan dengan teori dan pandangan, tetapi dengan sikap kami terhadapnya. Di sinilah letak yang tidak terartikulasikan dan orang mungkin mengatakan permintaan anonim agar kita menjaga kehidupan yang telah diberikan kepercayaan di tangan kita". (Løgstrup, 1997)

Tindakan solider terhadap korban virus Covid-19 dalam kehidupan sosial bukan berdasarkan pada aturan, perintah atau instruksi dalam masyarakat. Tindakan solidaritas atas orang lain mendahului segala peraturan. Dengan kata lain, sikap solidaritas adalah suatu fenomena ontologis dan sebaliknya bukan dibangun atas dasar fenomena psikologis (Thomassen, 1992). Løgstrup memberikan kritik yang sangat tajam terhadap tindakan moral dewasa ini yang sangat memberi penekanan pada prinsip-prinsip 
yang mengikuti aturan dan universal dalam kebanyakan teori moral Anglophone (Løgstrup, 1997). Akan tetapi solidaritas sebagai suatu prinsip dasar etis yang kaya dalam arti tidak terbatas pada satu sikap atau norma saja.

Penegasan tersebut mengungkapkan bahwa pada saat seseorang berhadapan dengan korban virus Covid-19, ia telah terikat dengan sikap solider dengan mereka karena relasi yang terjadi mendahului kesadarannya sebagai manusia. Dalam konteks ini, Løgstrup tidak memberikan sebuah aturan agar seseorang harus memperhatikan, menolong dan menghormati para korban virus Covid-19 karena pemikirannya bercorak fenomenologi yang menekankan sebuah fakta dalam kesadaran manusia saat berjumpa dengan orang lain (Thornton, 2017). Saat seseorang berhadapan dan bertemu dengan korban virus Covid-19, ia sudah terikat dengan tindakan solidaritas terhadapnya. Sikap solidaritas tersebut selalu bersifat absolut dan total. Tanpa mereka meminta pertolongan, perhatian dan belas kasih, seseorang telah lebih dahulu bersikap moral, karena permintaan itu tak terkatakan.

Uraian di atas memperjelas bahwa tanpa adanya perintah pihak lain seperti anjuran pemerintah atau agama, seorang individu sudah dan harus bertindak solider terhadap korban virus Covid-19. Karena bukan sebuah perintah, maka seseorang tidak bisa mengelak atau menolaknya. Hasil pemikiran Løgstrup ini serupa dengan konsep Levinas yang mengungkapkan bahwa "saya tersubstitusi atau berada pada tempat mereka yang menjadi korban dengan bersedia menanggung kemalangan, kesalahan, penderitaan dan kelukaannya" (Levinas, 1985). Realitas ini memberikan makna bahwa saat seorang individu melihat korban virus Covid 19, seluruh perhatiannya terbajak olehnya, karena tindakan solider tersebut bersifat total.

Konsekuensi dari tindakan solider yang total ini menghantar seorang individu menjadi penebus bagi korban Covid-19. Solidaritas mengandung suatu dasar penebusan. Tanpa diperintah, subyek moral telah terikat dengan tindakan solider dengan mereka. Solidaritas yang dipahami oleh Løgstrup berbeda dengan sikap 
solidaritas pada umumnya. Seseorang diwajibkan untuk selalu solider dengan orang lain. Beban pasien Covid-19 menjadi beban setiap individu. Ia bertanggung jawab atas luka dan penderitaan mereka. Dengan demikian, seseorang sebagai individu berusaha mengangkat korban Covid-19 untuk keluar dari segala penderitaan dan kemalangan yang dialami. Pemikiran Løgstrup serupa dengan pemikiran Levinas di mana tanggung jawab pada prinsipnya bersifat penebus. Saya bertanggung jawab atas kesalahan orang lain. Tanggung jawab atas orang lain menjadi tindakan penebusan. Artinya saya berusaha mengangkat orang lain keluar dari kesalahannya (Sobon, 2018). Baik Løgstrup maupun Levinas sangat menekankan akan perihal "mencintai orang asing" atau "mencintai sesama" (Stern, 2019).

\section{Solidaritas atas Pasien Covid-19 Selalu Bersifat Asimetris}

Dalam etika solidaritas Løgstrup, seorang melibatkan dirinya sendiri secara langsung terhadap para korban virus Corona. Ia yang bersikap solider dan selalu berdiri berdampingan mereka, membiarkan diri dan segala kehendaknya digunakan oleh mereka. Karena sikap solider yang total ini, maka solidaritas bukan termasuk suatu permintaan karena resiprositas. Dengan kata lain solidaritas tidak bersifat resiprositas tapi sebaliknya asimetris. Penegasan ini menjadi jelas dalam kutipan berikut ini,

Solidaritas tidak termasuk suatu permintaan karena resiprositas. Hal itu dapat melakukan seperti itu, hanya ketika seorang mempunyai suatu maksud bersama. Dalam kehidupan keluarga, cara demikian itu cukup pantas untuk meminta dengan tegas bahwa setiap orang mengambil bagian dalam kegiatan itu yang merupakan keperluan untuk memelihara kehidupan bersama. Tapi tidak ada resiprositas dalam hubungannya dengan solidaritas (Thomassen, 1992). 
Kutipan tersebut dapat disintesiskan bahwa setiap individu bertindak solider, membantu, menyelamatkan, menghidupkan dan memberikan sesuatu kepada korban virus Covid-19 tanpa mengharapkan dan menuntut sesuatu pada mereka. Tindakan solider yang diberikan kepada korban Covid-19 tidak ditandai resiprositas melainkan asimetris. Menurut Løgstrup, solidaritas terhadap mereka tanpa mengharapkan balasan. Eksistensi seorang individu sebagai manusia ditentukan oleh sikap solidaritas atas korban Covid-19. Eksistensi seorang individu ditentukan oleh sikap solider dengan sesama. Sedangkan, apakah kelak mereka itu bertindak solider balik atau tidak bukan hal yang sangat penting, karena seseorang ada untuk para korban Covid-19. Seseorang ada untuk (being for) bukan berada untuk (being-with) orang lain. Namun, pada hakikatnya menurut Løgstrup solidaritas itu selalu bersifat asimetris atau tindakan solidaritas tanpa mengharapkan balas jasa dari orang lain.

\section{Solidaritas atas Korban Covid-19 sebagai Fenomena Moral}

Solidaritas adalah suatu fenomena moral. Løgstrup menunjukkan bahwa dalam kehidupan sosial solidaritas tampak ketika seorang individu menolong pribadi yang lain. 'Dengan alasan ini, solidaritas adalah semangat dari suatu perintah untuk mencintai sesama' (Thomassen, 1992). Solidaritas didorong oleh kenyataan bahwa seorang individu lebih dahulu merasakan apa yang dirasakan oleh para korban Covid-19. Oleh karena itu, mencintai sesama lewat tindakan solidaritas tidak terbatas pada orang-orang yang sedang memberikan sesuatu pada orang yang sudah dikenal, tapi juga mencintai sesama mungkin terjadi terhadap orang asing atau bahkan musuh sekali pun. Penyebaran virus Corona menjadi fakta moral bahwa tindakan solidaritas harus diberikan kepada mereka semua yang menjadi korban Covid-19 tanpa mengenal batas sosial, agama, negara, ras ataupun budaya. Bencana dan wabah virus Corona menjadi masalah bersama dan harus diatasi bersama. Løgstrup menegaskan bahwa 'eksistensi 
seseorang sebagai manusia saling tergantung satu sama lain. Ia mempunyai kekuatan atas satu sama lain, dan harus belajar menggunakan kekuatan tersebut sedemikian rupa sehingga dapat membantu sesama' (Thomassen, 1992).

Bencana atau wabah epidemi seperti Covid-19 mudah ditaklukkan jika manusia yang memiliki kekuatan yang saling bersinergi, bekerja sama dengan pemerintah dan komponen bangsa. Hal ini serupa dengan konsep utama Løgstrup (1956) yakni ketergantungan pada orang lain tidak bisa dihindari; hidup seseorang saling terkait satu sama lain. Kesadaran ini merupakan persoalan bersama dan menggalang kekuatan bersama-sama untuk tolong-menolong menanggulangi wabah ini. Sikap solidaritas bagi korban virus Covid-19 menjadi fenomena moral yang harus dilaksanakan secara bersama. Sebaliknya, tindakan yang mementingkan diri dan kelompok masing-masing harus dihilangkan dan sangat tidak diperlukan saat ini. Solidaritas yang kurang memperhatikan kehadiran dan kondisi kelompok minoritas dapat dikatakan sebagai sebuah solidaritas semu. Penegasan ini serupa dengan pemahaman solidaritas yang dikemukakan oleh Emile Durkheim yakni "sebuah solidaritas yang sejati lahir dari keinginan untuk bersatu dengan sikap moral yang baik, tetapi solidaritas yang semu diwarnai dengan ketakutan, kebencian dan keterpaksaan. Solidaritas yang kuat adalah solidaritas yang dibangun bersama, sedangkan solidaritas yang dipaksakan 'dari atas' atau yang dipicu oleh rasa antagonisme terhadap pihak luar tanpa sungguh-sungguh dibentuk oleh hubungan kebersamaan." (Kurniawan, 2019).

Setiap individu termasuk pemerintah harus mengutamakan keselamatan orang banyak (rakyat) dibandingkan kepentingan lainnya, bahkan ekonomi sekalipun. Pada hakikatnya, masyarakat Indonesia terkenal dengan semangat suka menolong, tenggang rasa, baik hati, punya daya juang dan sikap solidaritas yang sangat tinggi. Kekuatan-kekuatan ini perlu ditingkatkan dan dikuatkan saat ini demi keselamatan korban Covid-19 yang sedang melanda tanah air. 


\section{Solidaritas: Bentuk Khas dari Cinta}

Løgstrup memahami solidaritas sebagai bentuk khas dari cinta, yaitu salah satu manifestasi kehidupan. Yang dimaksudkan adalah mencintai sesama manusia secara spontan, misalnya dengan memberikan pertolongan kepada korban Covid-19 tanpa mempertimbangkan untung-rugi. Solidaritas menjadi satu lahan bertumbuhan cinta terhadap manusia. Sebagai salah satu manifestasi dari kekuatan intrinsik dalam hidup manusia, maka kualitas cinta perlu dipelihara dan dibagikan kepada orang lain. Cinta dimengerti Løgstrup sebagai sesuatu yang penuh gairah dan memiliki karakter pemenuhan makna hidup. Cinta berperan sebagai landasan bagi kehidupan yang berarti dan memberikan pembebasan baik bagi orang yang mencintai maupun yang dicintai. Itulah aspek 'romantis' dari cinta yang amat ditekankan oleh Løgstrup ketika ia berdiskusi tentang kekuatan gairah cinta dan spontanitas. Menurutnya, dalam cinta seperti itu simpati sedemikian kuat sehingga objektivitas terhadap sesama manusia menjadi tidak mungkin.

Pada hakikatnya solidaritas merupakan kekuatan yang terkumpul untuk membela dengan gigih kaum tertindas, mereka yang menjadi korban virus Covid-19, korban kekerasan, kaum cacat dan kaum lemah. Jika kekurangan atau kesulitan itu akhirnya dapat diatasi, maka peranan solidaritas berakhir, tanpa lagi meninggalkan ikatan emosional. Solidaritas terutama merupakan sikap penghargaan dan keterbukaan terhadap mereka yang menderita dan tidak berbahagia.

Tindakan solidaritas adalah tindakan kemanusiaan dan bukan kegairahan. Ungkapan solidaritas terhadap para korban virus Covid-19 menjadi salah satu wujud penyerahan diri kepada mereka sekaligus keterlibatan diri. Artinya, dalam solidaritas orang tidak menenggelamkan diri ke dalam situasi atau keinginan orang lain, melainkan orang dituntut untuk berdiri di samping sesamanya. Sikap solidaritas harus dinyatakan tanpa mengharapkan apapun sebagai balasan. Solidaritas turut memelihara stabilitas keamanan 
dan keterlibatan. Dalam arti, orang yang solider memberikan rasa aman, rasa memiliki sahabat kepada orang lain.

\section{KESIMPULAN}

Prinsip solidaritas menjadi fenomena moral yang sangat penting untuk bertindak etis pada masa pandemi virus Covid-19. Bukan hanya pemerintah yang menjadi kunci solidaritas melainkan terletak pada tindakan setiap manusia sebagai individu kepada orang lain (korban Covid-19). Lewat hasil pemikirannya, Løgstrup mengemukakan bahwa sikap solidaritas terhadap para korban Covid-19 harus nyata dan bukan sekedar perasaan atau motivasi psikologis semata, melainkan turut ikut nyata membantu, menyelamatkan dan merasakan penderitaan yang dialami oleh korban Covid-19. Sikap solidaritas atas korban Covid-19 lahir bukan dari adanya perintah dari luar, melainkan karena kesadaran internal individu sebagai manusia yang bermoral. Bahkan tindakan solidaritas tersebut bersifat asimetris di mana setiap individu wajib menyelamatkan, menghidupkan, dan memberikan sesuatu yang bernilai kepada korban virus Covid-19 tanpa mengharapkan dan menuntut sesuatu pada mereka. Setiap individu hadir sebagai penyelamat bagi orang lain.

Salah satu karakteristik konsep solidaritas Løgstrup adalah bersifat asimetris. Asimetris berarti seorang individu memberikan perilaku solider terhadap orang lain tanpa mengharapkan balasan atau menuntut sesuatu pada orang tersebut. Artinya relasi solidaritas atas orang lain bersifat being-for, seseorang ada bagi orang lain, bukan orang lain ada bagi diriku. Pemikiran Løgstrup ini mendobrak pemikiran pendahulunya yakni Buber dalam pemahamannya tentang relasi antar manusia. Bagi Buber, salah satu karakteristik relasi antar manusia adalah ketimbal-balikan (resiprocity) atau mutualitas (mutuality). Realitas hidup manusia adalah perjumpaan. Perjumpaan seseorang dengan orang lain tidak pernah berhenti. Tidak mungkin ada relasi "Aku-Engkau" yang lengkap tanpa relasi timbal balik. Buber menulis, "relasi bersifat timbal balik. Sesamaku bertindak padaku sebagaimana saya 
bertindak padanya" (Buber, 1996). Singkatnya, bagi Buber relasi intersubyektif selalu berpola being-with dan karena itu simetris. Lewat relasi timbal balik, seseorang akan menemukan eksistensinya sebagai manusia.

Meskipun demikian konsep solidaritas Løgstrup yang bersifat asimetris memiliki kelemahan yakni konsep pemikirannya sangat menekankan aspek metafisika melalui pendekatan fenomenologi. Di samping itu, perlu disadari pula bahwa dalam relasi sosial, peranan orang lain sangat penting bagi eksistensi saya sebagai seorang individu. Tanpa perjumpaan dengan orang lain, relasi timbal balik dengan sesama, eksistensi saya sebagai individu tidak mungkin ada. Akhirnya, solidaritas menjadi satu lahan bertumbuhnya cinta terhadap manusia. Cinta sebagai salah satu manifestasi dari kekuatan intrinsik dalam hidup manusia. Cinta sebagai sesuatu yang penuh gairah dan memiliki karakter pemenuhan makna hidup.

\section{DAFTAR PUSTAKA}

Buber. (1996). I and Thou, translated by Ronald G. Smith Wiltshire: The Cromwell Press.

Jensen O. (2007). Historien om K.E. Løgstrup, [The history of K. E. Løgstrup]. København: Anis.

Kurniawan, Kevin, Nobel. (2019). Kisah Sosiologi: Ulasan Pemikiran Sosiologi dan Refleksi Kehidupan Relasi Manusia. FISIP: UI.

Levinas, Emmanuel. (1985). Ethics and Infinity. Translated by

Richard A. Cohen. Pittsburgh: Dusquesne University Press.

Løgstrup, K. E. (1956). Den Etiske Fordring. Copenhagen: Gyldendal (Original work published 1961)

Løgstrup K.E (1987). Solidaritet og Kxrlighed [Solidarity and Love], p. 116-163. Copenhagen: Gyldendal.

Løgstrup, K. E. (1997). The Ethical Demand. H. Fink (Ed.). Notre Dame University Press.

Løgstrup, K. E. (1971). The Ethical Demand. Trans. Th. I. Jensen, Philadelphia: Fortress Press. 
Løgstrup K.E. (1997). Beyond the Ethical Demand. Notre Dame, IN: Notre Dame University Press.

Norlyk A, Dreyer P, Haahr A. (2011). Understanding the creative processes of phenomenological research: The life philosophy of Løgstrup," dalam International Journal of Qualitative Studies on Health and Well-being, 08 Nov 2011, 6(4) DOI: 10.3402/qhw.v6i4.7320

Pahuus M. (2005). K.E Løgstrups Eksistentielle Fænomenologi [Løgstrup's Existential Phenomenology], p. 117-127. SlagmarkTidsskrift for Idéhistorie. Denmark

Randi, Sviland., Kari Martinsen., David A. Nicholls. 2020. "Løgstrup's thinking: a contribution to ethics in physiotherapy," dalam Journal Physiotherapy Theory and Practice: An International Journal of Physical Therapy, https://doi.org/10.1080/09593985.2020.1741051

Sobon, Kosmas. (2018). “Konsep Tanggung Jawab Emmanuel Levinas," dalam Jurnal Filsafat Fakultas Filsafat Universitas Gadjah Mada, Vol. 28. No 1 Tahun 2018. https://jurnal.ugm.ac.id/wisdom/article/view/31281

Stern, Robert. (2019). The Radical Demand in Logstrup's Ethics. The United States of America: Oxford UniversityPress.

Sudibjo. (2004). “Solidaritas," dalam Ensiklopedi Nasional Indonesia. Jakarta: PT Delta Pamungkas.

Thomassen, Niels. (1992). Communicative in Theory and Practice, translated by John Irons. London: The Macmillan Press.

Thornton, Simon. (2017). The Phenomenologi of Moral Agency in the Ethics of K.E. Løgstrup. Department of Philosophy University of Essex.

Zygmunt, Bauman. (1993). Postmodern Ethics. Oxford: Basil Blackwell. 